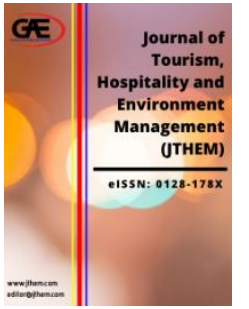

\author{
JOURNAL OF TOURISM, \\ HOSPITALITY AND \\ ENVIRONMENT MANAGEMENT \\ (JTHEM) \\ www.jthem.com
}

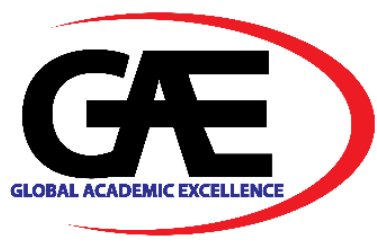

\title{
THE RELATIONSHIP BETWEEN ENTREPRENEURIAL ORIENTATION AND PRODUCT DEVELOPMENT PERFORMANCE IN FAMILY BUSINESS LOCATED IN JAVA AND BALI: THE MODERATING ROLE OF NETWORKING CAPABILITY AND ENVIRONMENTAL DYNAMISM
}

\author{
Carolina Novi Mustikarini $^{1 *}$, Christina Yanita Setyawati ${ }^{2}$ \\ 1 Business Management, Universitas Ciputra, Surabaya, Indonesia \\ Email: cmustikarini@ciputra.ac.id \\ 2 Business Management, Universitas Ciputra, Surabaya, Indonesia \\ * Corresponding Author
}

\section{Article Info:}

Article history:

Received date: 13.07.2020

Revised date: 10.08 .2020

Accepted date: 30.09 .2020

Published date: 01.12.2020

\section{To cite this document:}

Mustikarini, C. N., \& Setyawati, C. Y. (2020). The Relationship Between Entrepreneurial Orientation and Product Development Performance in Family Business Located in Java and Bali: The Moderating Role of Networking Capability and Environmental Dynamism. Journal of Tourism, Hospitality and Environment Management, 5 (21), 5273.

\section{DOI: $10.35631 / J T H E M .521004$.}

This work is licensed under CC BY 4.0

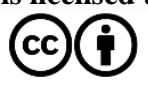

Abstract:

Product Development Performance (PDP) has an important role to achieve the competitive advantage of the company so that the managerial role is a major factor that can contribute to the success of product development. One of the important factors for understanding Product Development Performance is how a corporate applied the strategic corporate orientation optimally. Strategic orientation can be interpreted as a strategic direction that is determined to be applied by a company as a means of creating the right behaviour in achieving sustainable superior business performance. In this research, we focused in Entrepreneurial Orientation that has been developed in family businesses. Strategic orientation became an important antecedent in enhancing the development of product performance (PDP) because some researchers stated a deeper understanding related to the role of Entrepreneurial Orientation (EO) is needed especially in family businesses. The development of product performance is also supported by other factors, they are Network Capability and Environmental Dynamism. These findings explained that entrepreneurial orientation has a significant positive effect on product development performance when a company has adequate networking capability to manage environmental dynamics. Therefore, this study is focused on looking at the effect of Entrepreneurial Orientation on Product Development Performance with Networking Capability and Environment Dynamic as moderating. The research approach taken is quantitative research, which used data presented in the form of numbers or numerical information. The population in this research is family businesses that are located in Java and Bali, Indonesia and the number 


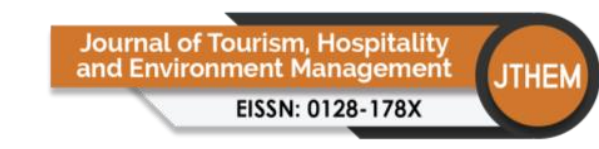

Volume 5 Issue 21 (December 2020) PP. 52-73

DOI 10/35631/JTHEM.521004

is unknown. This study found that family businesses have entered the survival phase have a long-term entrepreneurial orientation, which means that they are able to manage opportunities innovatively by being more proactive in all conditions, and it has an effect on the performance of product/service development. The networking capability has opportunities as an antecedent that can affect the performance of product/service development while environmental dynamism is only a potential moderator.

Keywords:

Environment Dynamic, Entrepreneurial Orientation, Networking Capability, Product Development Performance

\section{Introduction}

The growth of family businesses in Indonesia over the past 12 months has increased compared to 2016 . It showed that $65 \%$ has experienced growth and only $7 \%$ has decreased so that globally family business growth reached 69\% (PWC, 2020). Business in Indonesia globally is more likely to experience rapid and aggressive growth, and current international sales growth of $16 \%$ is a contribution from the turnover of family businesses in Indonesia and is expected to grow to $27 \%$ within five years (PWC, 2020). The main challenges for Indonesian's family businesses in the next two years are improvements in accessing right skills and abilities, innovating to stay ahead, economic environment and competition. The important thing in meeting personal and business goals is the maintenance of the best talent (through recruitment and retention), in addition to that innovation and profitability are also the keys to success. In connection with strategic planning, there is a fact which states that $17 \%$ do not have a medium-term plan.

More than one third (35\%) of Indonesian's family businesses want to change the business model over the next two years (20\% globally) and $81 \%$ will place individuals who have professional expertise from outside the family to be able to contribute to the business (PWC, 2020). $63 \%$ of family businesses in Indonesia will make a significant step in terms of digital capabilities in the next two years, while there is also data that shows $46 \%$ of family businesses feel vulnerable to digital disruptions which is more than doubled in 2016, and higher than $30 \%$ globally (PWC, 2020). Based on these data, the dynamics of the management in family businesses are certainly faced with conditions that are always dynamic and full of uncertainty.

Uncertainty in an ever-changing and unpredictable environment encourages companies to access competitiveness in improving the long-term performance of the industrial sector (Hosseini et.al., 2012). Agbim et.al. (2014) states that many companies try to improve business performance by accessing information from the business environment, so as to maintain the level of interest and frequency in the business environment. The findings of Hung and Chou (2013) show that technology and market can positively increase or decrease the effect on company performance. Hung \& Chou (2013) explains one way to survive in a dynamic business environment, it must innovate and develop in various aspects so it can improve company performance in environmental turbulence. Hung \& Chou (2013) added that environmental turbulence can be influenced by technological turbulence and market turbulence, so it is possible that environmental dynamics can increase or decrease company performance. 




Volume 5 Issue 21 (December 2020) PP. 52-73

DOI 10/35631/JTHEM.521004

Seeing the dynamics that cannot be predicted, many companies try to access sensitivity to uncertain conditions. Adomako and Danso (2018) states that networking capability is one of the important things that a family company must have in order to survive in all conditions. Networking capability is the ability possessed by businesspeople to build relationships with buyers, suppliers and competitors. Anwar et al. (2018) states that networking capability is needed in establishing relationships with suppliers, buyers and competitors so that without such a relationship it is impossible for the company to survive.

Zahra (1993) found that there was a strong positive relationship between entrepreneurship and performance among firms in dynamic growth environments. It showed that the relationship was largely negative among the firms present in static and impoverished environments whereas Miller (1988) found that innovative strategies in uncertain (unpredictable and dynamic) environments were associated with higher performance. Those became reasons to believe that performance implications can be influenced EO positively. A general tendency in today's business environment is the shortening of product and business model life cycles (Hamel, 2000). Consequently, the future profit streams from existing operations are uncertain and businesses need to constantly seek out new opportunities. An EO can assist companies in such a process.

Several empirical studies find support for EO's positive impact on performance (Zahra, 1991; Zahra and Covin, 1995; Wiklund, 1999). This can be explained that entrepreneurial orientation has a significant positive effect on product development performance when a company has adequate networking capability to manage their environmental dynamics. This is important for family business management because there is a competency gap between generations. That is why it is very important to know the conditions of dynamic environmental whether next generations have the same orientation as the predecessor generations. Regarding the involvement of the next generation in managing the family business, of course, it is not just continuing, but also providing a different and new improvement in the family business, especially if it is related to product or service development. Therefore, this study is focused on looking at the effect of Entrepreneurial Orientation on Product Development Performance with Networking Capability and Environment Dynamic as moderating.

\section{Literature Review}

\section{Product Development Performance}

Product development is a series of development activities, production and delivery of new products to the market. Various models have been proposed to describe or manage the product development process. Most of these models focus on activities (Saren, 1984) or stage gate models (Cooper, 2008). While the need for internal functions to collaborate in the process turned out to be an unmatched thing. Furthermore, similar techniques and concepts in the 1980s were increasingly revealed by researchers who also stressed the importance of external collaboration, namely with suppliers and customers. However, internal and external collaboration cannot clearly produce positive results for the company, where some researchers find positive effects (Droge et. al., 2004; Koufteros et al., 2005; Mishra and Shah, 2009; Lau, 2011; Johnson and Filippini, 2013), other mixed results (Fang, 2008), as well as negative effects (Eisenhardt and Tabrizi, 1995). In such inconsistencies, there may be differences in conceptualization, operationalization, measurement, analytical methods and / or lack of consideration of certain antecedents. 


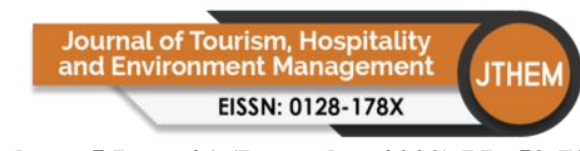

Volume 5 Issue 21 (December 2020) PP. 52-73

DOI 10/35631/JTHEM.521004

Therefore, developing and enhancing collaborative competence can be considered as one of the action programs that companies can implement to translate strategic objectives and product development priorities so that it becomes an action and also to overcome the complexity of products and processes. However, the role of this antecedent in collaborative competence in the context of product development has not received adequate attention. Some previous studies define new products with different definitions based on the product, manufacturer, consumer, or product life cycle. The performance of new product development is multidimensional construction. Researchers use various measures of performance evaluation based on different research focuses.

The performance of new product development in this study includes market performance, financial performance, customer performance, and product performance. Furthermore, several studies explain the key factors for successful new product development, including (1) the company must have a new high-quality product process and design a new product with customer orientation; (2) companies must be able to define new product strategies, including goals, objectives, and strategic focus areas; (3) senior management must make the necessary commitment of resources for new products and product development; (4) the company must have a high-quality new product team, including dedicated team leaders, strong and frequent communication and interaction, fast and efficient decision making, etc.; (5) the company must have an innovative climate and culture, in addition it also shows that the key factors for the successful development of new products consist of (i) cross-functional team to make marketing decisions and key making; (ii) high quality sales, advertising, and technical support efforts; (iii) involves logistics at the beginning of planning; (iv) good launch management and good support management programs; (v) the estimated time to launch; (vi) gathering information about market testing, customer feedback, advertising testing, etc (Hsu and Fang, 2009).

Companies must excel in exploitative and explorative innovation to achieve success, or even survive (Tushman and O'Reilly III, 1996), it means that Continuous investment in the ability to exploit and explore is expected to create competitive advantage (Soosay and Hyland, 2008) and if giving inadequate attention to one can cause a decline in organizational performance (Atuahene-Gima, 2005). Companies need to ensure that there is a balance between exploration and exploitation (March, 1991), even though the combination of exploitation and exploration is felt to be difficult for the company (March, 1995). As such, some companies prefer a more exploitative strategy, while others might choose a more exploratory strategy.

In addition, several companies pursue both, where the choices made by companies in terms of pursuing exploitative or explorative strategies also depend on market turbulence and the intensity of competition (Molina-Castillo et al., 2011). Various intra-organizational arrangements have been proposed to overcome the tension between exploitation and exploration, where there are suggestions that are made and are more concrete than others, including organizational ambition (Tushman and O'Reilly III, 1996; Birkinshaw and Gupta, 2013), multiple organizations (Duncan, 1976; Sutcliffe et al., 2000), process management (Benner and Tushman, 2003), mass customization capabilities and innovative ambidexterity (Kortmann et al., 2014), and quality management (Asif and de Vries, 2015).

In product development, various researchers focus more on cross-functional coordination and collaboration between marketing, product development, and production (Bergen and 


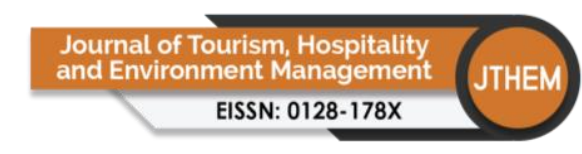

Volume 5 Issue 21 (December 2020) PP. 52-73 DOI 10/35631/JTHEM.521004

McLaughlin, 1988; Langowitz, 1989; Voss and Winch, 1996; Sherman et al., 2000; Swink and Calantone, 2004; Atuahene-Gima, 2005; Partanen and Haapasalo, 2004; Ahmad et al., 2010). It means that collaborative arrangements between organizations, namely collaboration with customers, suppliers and even competitors, have proven to be very relevant to overcome the tensions that arise in product development (Faems et al., 2005) and enable companies to make product development faster and with more varied products (Ryall, 2013). Collaboration involves sharing information and assimilating technology, knowledge and processes to develop products that can meet market needs (Chang and Taylor, 2016), so that absorption capacity is needed, which is a collection of routines needed to acquire, disseminate, change, and exploit knowledge (Cohen and Levinthal, 1990; Lawson and Potter, 2012). This is based on the resource-based view (RBV), collaborative competence and absorptive capacity can be considered as a collection of routines that constitute resources (Shah and Ward, 2003), which tend to be emulated by competitors or bought in factor markets.

\section{Entrepreneurial Orientation}

Entrepreneurial orientation shows the extent to which business strategies within a company are oriented towards the achievement of new market opportunities and the occurrence of updates in existing operations through innovation (Lumpkin and Dess, 1996). This places an emphasis on how to find external opportunities and make a commitment to resources for enhancing internal innovative behavior and competitive advantage (Covin and Slevin, 1989; Wu et al., 2008). The entrepreneurial orientation reflects the level of risk taking, proactivity, and aggressiveness of the company with regard to innovation (Becherer and Maurer, 1997; Atuahene-Gima and Ko, 2001; Bhuian et al., 2005). Entrepreneurial values enhance organizational transformation and renewal, can help build new competencies, and create new business within existing businesses. Entrepreneurial orientations are willing to take risks to find market opportunities and therefore use these opportunities to develop and introduce new products to the market, so that they gain first mover advantage (Han et al., 1998; Hurley and Hult, 1998). In addition, companies also anticipate and act on market opportunities directing companies to take initiatives and act optimally in the market (Venkatraman, 1989; Wu et al., 2008). Therefore, entrepreneurial orientation can foster the company's innovative capabilities by taking advantage of emerging market opportunities and by targeting premium market segments so that it can benefit the commercialization of new product development (Lumpkin and Dess, 1996).

Research in the field of entrepreneurship has shown that new businesses often fail to translate entrepreneurial orientation into higher performance due to lack of strategic resources (Hitt et al., 2001). Thus, entrepreneurial orientation can only facilitate wealth creation when companies strategically acquire, develop, and utilize resources that can foster opportunities seeking behavior and create profits (Ireland et al., 2003). This enables companies to take advantage of opportunities that arise and is therefore an important driver of new products and organizational growth (Slater and Narver, 1994; Hult et al., 2004; Bhuian et al., 2005; Luo et al., 2005). Employee orientation relates to the company's internal focus on human resources, placing employee welfare and satisfaction above other stakeholders (Fritz, 1996; Harris and Ogbonna, 2001; Piercy et al., 2002). Employee-oriented companies are characterized by a centralized decision-making process, investments in employee development, and delegated responsibilities. This tends to increase the satisfaction, motivation, and commitment of organizational members (Fritz, 1996; Ruekert, 1992). 


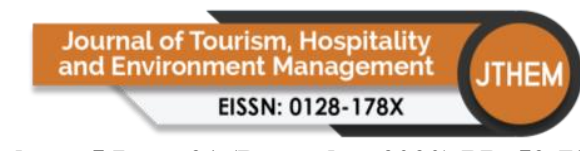

Volume 5 Issue 21 (December 2020) PP. 52-73

DOI 10/35631/JTHEM.521004

Furthermore, some previous research also shows the positive effect of employee orientation on performance, showing that satisfied, motivated and committed employees create satisfied and loyal customers, which, in turn, tends to increase the company's revenue stream (Ruekert, 1992; Fritz, 1996; Pfeffer and Veiga, 1999; Harris and Ogbonna, 2001). In addition, there are also studies that show a negative relationship between entrepreneurial orientation and performance in some circumstances, which is contrary to the positive relationship between entrepreneurial orientation and the performance of commercialization of new products.

\section{Networking Capability}

A company's ability to manage its network can be important for resource distribution, identification of opportunities and exploitation so that it impacts on the company's overall performance (Dyer and Singh, 1998). As such, a new business must have the ability to manage strategically and properly manage their network ties and resources so as to achieve successful growth. This means that network capabilities can help companies achieve this (Dyer and Singh, 1998; Walter et al., 2006; Reinartz et al., 2004; Swaminathan and Moorman, 2009; Mitrega et al., 2012). Therefore, network capability is defined as the process by which companies find, manage and utilize their social ties, contacts and connections over time that aims to develop and grow through their social networks.

Formally, network capability is the company's ability to systematically and competently exploit and explore social ties, contacts, and connections that complement each other with external entities to mobilize and use network resources to create products and services so that they have added value as time begins from the market appear, collide, split, evolve and die. The definition shows the existence of multiple processes of networking, relationship coordination, the ability to adapt relationships and relationship experiences during company development over time. Therefore, most researchers define that network capability is the ability that companies have to manage relationships between companies. This concept gives rise to the assumption that network capability focuses more on company-specific networks rather than the specific constituent skills needed to manage a single network (partners). In addition, this network capability not only facilitates theoretical expansion in the literature on network structure, but also highlights the importance for companies to consider network dynamics and network management processes. Furthermore, network capability is also defined as the company's ability to find network partners and manage network relationships to create competitive advantage so that network capabilities can be seen from two dimensions, where the first dimension, finding network partners which refers to the extent of the search by the company to identify individuals or organizations the right company to want to interact, while the second dimension, managing network relationships shown by the relational skills of a company in managing effective and efficient network relationships with resource persons or organizations. This is in line with the literature, where to obtain the benefits embedded in the network, the company must take deliberate actions to improve its capabilities in 1) choosing the right network partner, 2) setting up the right enterprise-level management mechanism to navigate various complex network activities with partners. Furthermore, recent research shows that network capability is positively related to company performance, and network structure may have a contingency value on the results of company performance, so it is important to understand the most influential social network bond patterns. In this study the focus is on two network structures: strong ties, bridge ties, and their relationship to network capabilities on product development performance. 




Volume 5 Issue 21 (December 2020) PP. 52-73 DOI 10/35631/JTHEM.521004

\section{Environmental Dynamism}

Environmental dynamics refers to the speed of change and market instability and technological environment where high environmental dynamics can reflect a high frequency of unexpected new changes that make it difficult for companies to respond by referring to the breadth of searches the company does to identify individuals or organizations that are right with companies that want to interact determine the objective and formal procedures. Companies that operate in a dynamic environment should use appropriate new technology, develop new products, actively conduct market and customer analysis, arrange to benefit in the market, develop, maintain strategic flexibility, take proactive and innovative strategies, and be oriented future. If the company does not understand the level of environmental change, it will fail to capture the best opportunities that arise in the market. Prior research has supported the view that a dynamic environment tends to positively moderate the entrepreneurial orientation and performance relationship (Casillas et al., 2011; Lumpkin and Dess, 2001). There is also evidence in the family business literature that, as environmental dynamism increases, family firms with higher levels of entrepreneurial orientation will have stronger performance (Casillas et al., 2010; Cruz and Nordqvist, 2012).

High environmental dynamics can lead to the need for efficiency and flexibility in order to achieve success in the development and commercialization of its products. Efficiency in product development and commercialization requires deep exploitation of a strong bond that is by getting a degraded information flow, technological innovation, and operational support to facilitate the companies involved in improving existing products. Products developed by the company in this case are incremental, where additional product innovations can help companies generate additional revenue and ensure cost reductions and increased efficiency. In this case, network capabilities can help companies utilize existing ties to ensure better financial and economic stability in times of uncertainty.

\section{Entrepreneurial Orientation and Product Development Performance}

The three dimensions of entrepreneurial orientation (EO) are risk taking, innovation, and proactiveness, suggested by Miller (1983) derived from a review of the strategy-making process based on Mintzberg (1973) and Khandwalla (1977), also from entrepreneurship (Miller, 2011). Three dimensions of the EO constructs, namely competitive aggressiveness, proactive, and autonomy, suggested by Lumpkin and Dess (1996) can be described as EO domains (Wales et al., 2013). Although the dimensions of EO are different, they are strongly related and showed high mutual relations each other (Rauch et al., 2009). The EO dimension estimates that different EO dimensions must be relates to performance in the same way. However, experts said that dimension of EO may relate differently to company performance (Rauch et al., 2009) and there are studies to know advance alternative to EO constructs and conditions as alternative conceptualizations (Covin et al., 2006). In this study, EO is used as a multidimensional construction testing competitive aggressiveness, proactiveness, and innovation as EO dimensions related to product/service development performance.

Companies can adopt EO to get more benefit, such firms innovate frequently while taking risks in their product market strategies (Miller \& Friesen, 1982). Efforts to anticipate demand and aggressively position new product/service offerings often result in strong performance (Ireland, Hitt, \& Sirmon, 2003), it means that conceptual arguments suggest that EO leads to higher performance. While some studies have found businesses that adopt a strong entrepreneurial orientation perform much better than firms that do not adopt an entrepreneurial orientation 
(Covin \& Slevin, 1986; Lee, Lee \& Pennings, 2001; Hult, Snow, \& Kandemir, 2003; Wiklund \& Shepherd, 2003), other studies reported lower correlations between EO and performance (Zahra, 1991; Lumpkin \& Dess, 2001; Dimitratos, Lioukas, \& Carter, 2004) or were even unable to find a significant relationship between EO and performance (Covin, Slevin, \& Schultz, 1994; George, Wood, \& Khan, 2001). Thus, there is a considerable variation in the size of reported relationships between EO and business performance. Then, the relationship between EO and performance across previous studies showed moderators of the EOperformance relationship. In this research, strategic orientations are positively related to three aspects of new product commercialization, namely new product advantage, new product newness, and number of new products introduced to the market. Interestingly, we find that pairs of strategic orientations support each other in exerting their impacts on new product commercialization performance. In addition, we find that organizational learning mediates the effects of strategic orientations on new product commercialization and that environmental dynamism moderates the effect of strategic orientations on new product commercialization. We obtain the valuable insight that a firm's successful commercialization of new products hinges upon the development of critical (Mu and Benedetto, 2011a), yet complementary sets of strategic orientations, especially in a dynamic business environment ( $\mathrm{Mu}$ and Benedetto, 2011b). Based on the discussion, here is the conceptual framework (see Fig. 1).

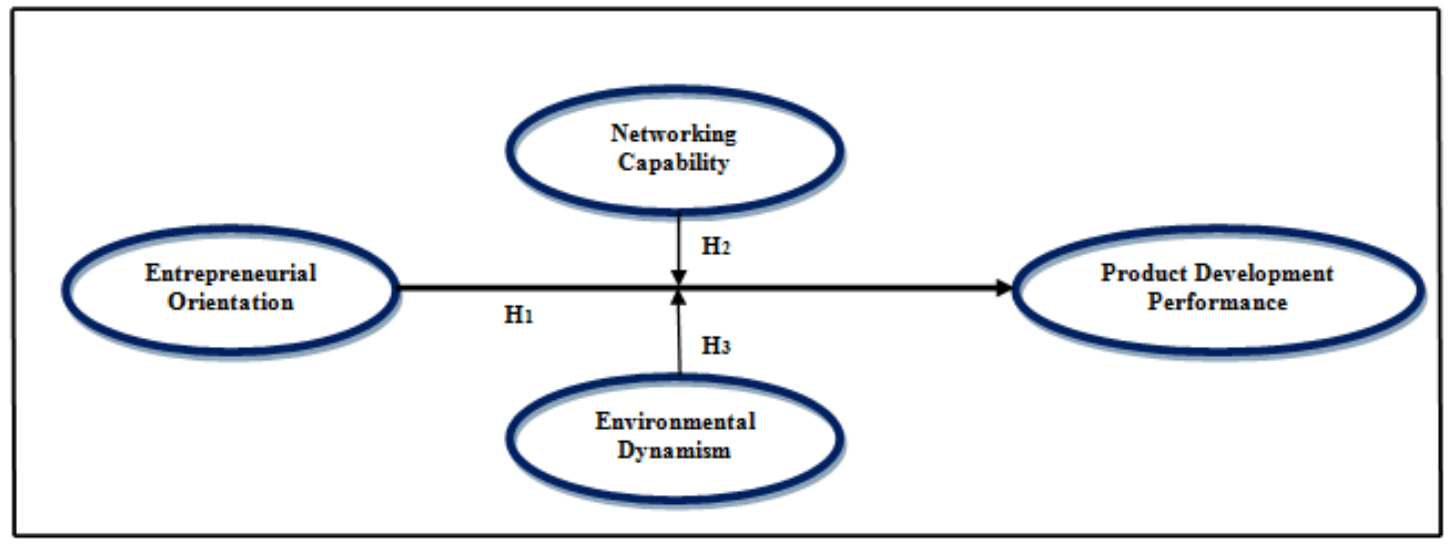

Figure 1. Conceptual Framework

\section{Methodology}

The research approach taken is quantitative research, according to Neuman (2015) techniques in quantitative research produce data presented in the form of numbers or numerical information. Population is all elements such as individual groups or objects that fit the research criteria (Grove, et.al., 2015). The sample is a sub-group or sub-set of the population (Sekaran \& Bougie, 2016). The population in this study is a family company in Java and Bali with an unknown population, so it can be mentioned that the population of this study is infinite. According to Sugiyono (2010), to determine a sample with an unknown population, the determination of the number of samples in this study uses the following formula:

$\mathrm{N}=$ Number of samples

$\mathrm{Z}^{2}=$ Confidence level $(95 \%$ or $\mathrm{Z}=1.96)$

Moe $=$ Margin of error (maximum sample error rate that can still be tolerated $=10 \%$ ) 


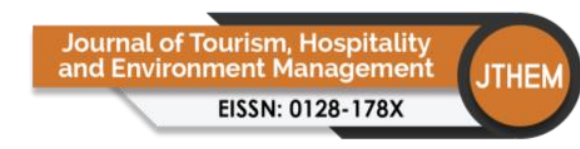

Volume 5 Issue 21 (December 2020) PP. 52-73 DOI 10/35631/JTHEM.521004

After using the formula, the required number of samples was 96.04 and rounded up to 97 respondents needed for this study (Sugiyono, 2010). The sample selection technique in this study uses convenience sampling technique. Convenience sampling is often used in a study which is the fastest technique to get basic information efficiently because of its easy accessibility (Sekaran \& Bougie, 2016). The sample in this study is a family company that has been managed by the next generation, with individual analysis units that can be represented as a family business.

The analytical tool used in this study is the Partial Least Square (PLS) method using the SmartPLS 3.0 program. Validity test by looking at the Average Variance Extracted Value (AVE) for each variable $>\mathrm{R}^{\wedge} 2$ and the cross loadings value $>0.5$ is declared valid (Hair et al. 2017), and the Reliability Test Value is seen from the Cronbach's alpha value and composite reliability $>0.6$. Significance test in testing the inner model and moderation effect can be seen in the value of the path coefficient or total effect. According to Sharma and Kim (2013) moderation variables are classified into 4 types namely pure moderation, quasi moderation, moderation potential, and moderating predictors. The following Table 1 is a classification of types of moderation.

Table 1 Moderation Type Classification

\begin{tabular}{lll}
\hline \multicolumn{1}{c}{ Moderation type } & \multicolumn{1}{c}{$\begin{array}{c}\text { Interaction of } \mathbf{M} \\
\text { (moderator variable) }\end{array}$} & \multicolumn{1}{c}{$\begin{array}{c}\text { Moderating Effect } \\
\mathbf{Y = f ( X , M )}\end{array}$} \\
\hline Pure Moderation & No Interactions & Significantly Moderated \\
Potential Moderation & No Interactions & Not Significantly Moderated \\
Quasi Moderation & There are interactions & Significantly Moderated \\
Predictor Moderation & There are interactions & Not Significantly Moderated \\
\hline
\end{tabular}

Source : Sharma, et.al. (1981)

\section{Findings and Discussion}

\section{Sample Characteristics}

The respondents of this study are family business owners who have actively contributed to the management of their family businesses. Table 2 shows respondents' characteristics. There are 40 respondents so that the response rate is $42.2 \%$. Based on Table 2, there are informations that show that most of the family company industries are companies engaged in the service industry, amounting to $42.5 \%$. The data provides relevance that the service industry has the opportunity to be more able to innovate in product development, this can be supported by the ability of businesspeople in networking (networking capability). The service industry is also an industry that is highly engaged with customers so that it is easier to interact in engaging.

Table 2 Respondents' Characteristics

\begin{tabular}{lrr}
\hline Sample Characteristics & Frequency & \% \\
\hline Industry & & \\
$\quad$ Retail & 12 & $30 \%$ \\
Manufacture & 10 & $25 \%$ \\
Services & 17 & $42,5 \%$ \\
$\quad$ Others & 1 & $2,5 \%$ \\
Company ownership & & \\
$\quad 1^{\text {st }}$ Generation & 1 & $2,5 \%$ \\
\hline
\end{tabular}




\begin{tabular}{crr}
\hline $2^{\text {nd }}$ Generation & 29 & $72,5 \%$ \\
$3^{\text {rd }}$ Generation & 9 & $22,5 \%$ \\
$4^{\text {th }}$ Generation & 1 & $2,5 \%$ \\
Firm Age & 6 & $15 \%$ \\
Less than 6 years & 8 & $20 \%$ \\
6 up to 10 years & 1 & $2,5 \%$ \\
11 up to 15 years & 13 & $32,5 \%$ \\
16 up to 20 years & 12 & $30 \%$ \\
More than 20 years & 40 & \\
Numbers of firms' owners &
\end{tabular}

Source : Processed Data

Regarding the generation criteria, $72 \%$ are second generation. The second generation is often referred to as the survival generation. According to Lansberg (1999) a survey conducted around the world shows a low "survival rate" of family businesses, which explains that there are only $30 \%$ of family businesses worldwide that can survive into the second generation. That is, $70 \%$ of family businesses fail to achieve success in the hands of the second generation. The data becomes interesting when in this study most are second generation, so they can contribute to the findings in this study.

The age data of the businesses in this study are mostly companies that have long operated, for examples, there are $32.5 \%$ aged 16 to 20 years and some $30 \%$ of companies have more than 20 years old. This information gives confidence that these companies can be said as family businesses that can last more than a decade or more, so that the data obtained has the opportunity to have optimal results.

\section{Validity and Reliability}

Data analysis will begin by testing the validity and reliability, after which the model structure will be tested. According to Baron and Kenny (1986) in Abdillah and Jogiyanto (2015) in moderation testing the inner model test can be done when the independent variable and the dependent variable have a significant effect (main effect testing). This is a requirement for continuing further testing. The main effect test results will test the significance of the effect of the Entrepreneurial Orientation (EO) on Product Development Performance (PDP). The following Table 3 shows the results of the validity and reliability in this study.

Tabel 3 Construct Means, Standard Deviations, Reliabilities, Validity and Correlations

\begin{tabular}{rllll}
\hline & $\mathbf{1}$ & $\mathbf{2}$ & $\mathbf{3}$ & $\mathbf{4}$ \\
\hline 1. Entrepreneurial Orientation & 0,522 & & & \\
2. Environment Dynamic & & 0,523 & & \\
3. Networking Capability & & & 0,510 & \\
4. Product Development & & & & 0,501 \\
$\quad$ Performance & & & & \\
Mean & 0,302 & 0,228 & 0,474 & - \\
Standard Deviation & 0,140 & 0,124 & 0,141 & - \\
Cronbach's Alpha & 0.837 & 0,583 & 0,912 & 0,857 \\
Composite Reliability & 0,885 & 0,812 & 0,926 & 0,892 \\
\hline
\end{tabular}


Table 3 shows that the variables in this study have met the Average Variance Extracted (AVE) value, which is that each variable has a cross loadings value> 0.5 (based on criteria in SmartPLS) so that it can be declared valid. The reliability test was in accordance with the criteria of Cronbach's alpha value and composite reliability> 0.6, so it was stated that the item measurement tool used in this study was classified as very good and reliable to use.

\section{Results}

\section{Structure Model Testing}

Hypothesis testing will begin with testing the structure of the main model, Figure 2 below is the result of testing the main effect.

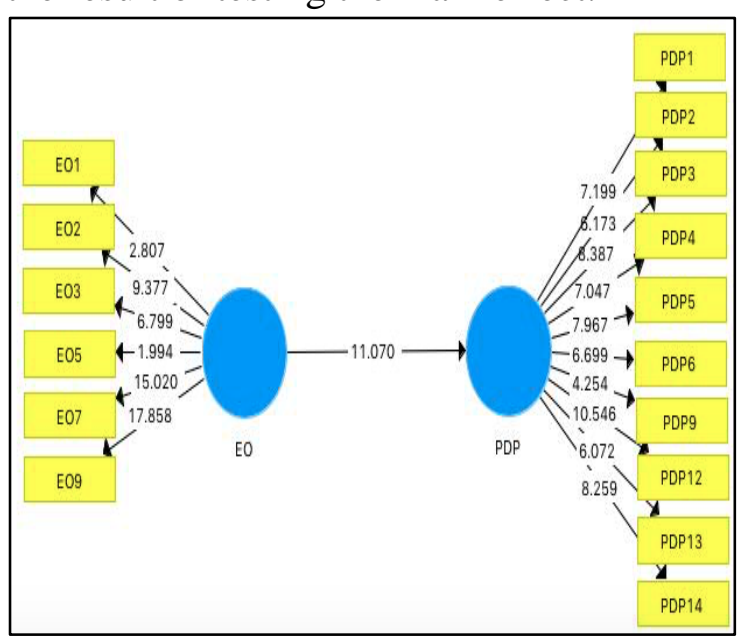

Figure 2. Main Effect Testing Results



Figure 3. Inner Model Test Results

Based on Figure 2, it can be seen that the t-statistic value between variables of 11.070 shows that there is a significant relationship between entrepreneurial orientation $(\mathrm{X})$ and product development performance $(\mathrm{Y})$. Testing significant main effects, the inner model testing can be continued by adding moderation variables to the research model. The results of testing the structural model (inner model) in this study are shown in Figure 3.

Figure 3 shows that the t-statistic value of the influence of the variable networking capability (NC) and product development performance (PDP) of 3.093 is significant with a t-statistic value more than 1.96 and the $t$-statistic moderating effect value of 1.325 can be interpreted that the networking capability variable (NC) does not moderate the effect of entrepreneurial orientatiom (EO) variables on product development performance (PDP). The t-statistic value of the effect of dynamic environment variable (ED) on product development performance (PDP) shows a value of 0.263 so that it is not significantly influential and the moderating value of the dynamic environment variable shows the result of t-statistic moderating effect of 0.316 so that it can be interpreted that the dynamic environment variable (ED) does not moderate the effect of entrepreneurial orientatiom variables (EO) on product development performance (PDP).

Networking capability is a type of moderating predictor which means that networking capability (NC) variables can potentially be an independent variable while the environment dynamic (ED) variable is a type of moderation potential (homologous moderation) which 
means it still has the potential to become a moderating variable where the effect affects the strength of the relationship between variables independent and dependent variable. In the structural model test (inner model) the thing to consider is the value of $\mathrm{R}^{2}$. The value of $\mathrm{R}^{2}$ is used in measuring changes in the variation of the independent variable on the dependent variable. A high $\mathrm{R}^{2}$ value indicates that the research model used is getting better (Abdillah and Jogiyanto, 2015). The following Table 4.3 presents the $\mathrm{R}^{2}$ or $\mathrm{R}$ Square values used in this study.

Table 4. R Square

\begin{tabular}{cc}
\hline \multicolumn{2}{c}{$\boldsymbol{R}$ Square } \\
\hline Variable & $\boldsymbol{R}$ Square \\
Product Development Performance & 0,661 \\
\hline
\end{tabular}

Source: data processed

Table 4 shows the $\mathrm{R}^{2}$ value of the product development performance (PDP) variable is 0.661 . The results of the $\mathrm{R}^{2}$ value illustrate that the product development performance variable can be explained by $0.661(66.1 \%)$ by the entrepreneurial orientation, networking capability, and dynamic environment variables, while the remaining $33.9 \%$ is explained by other variables outside the research model.

Path Coefficient and Total Effect

Table 4. Path Coefficient and Total Effect

\begin{tabular}{cccccccc}
\hline \multirow{2}{*}{ Hypothesis } & Path from & $\begin{array}{c}\text { Path } \\
\text { to }\end{array}$ & $\begin{array}{c}\text { Path } \\
\text { estimate } \\
\text { (t statistic) }\end{array}$ & $\begin{array}{c}\text { p- } \\
\text { value }\end{array}$ & $\begin{array}{c}\text { Path } \\
\text { estimate } \\
\text { (t statistic) }\end{array}$ & $\begin{array}{c}\text { p- } \\
\text { value }\end{array}$ & Result \\
\hline \multirow{2}{*}{$\mathrm{H}_{1}$} & $\begin{array}{c}\text { Environmental } \\
\text { Dynamism }\end{array}$ & PDP & 3,206 & 0,001 & 3,206 & 0,001 & \\
\hline $\begin{array}{c}\text { Networking } \\
\text { Capability }\end{array}$ & PDP & 3,093 & 0,002 & 3,093 & 0,002 & \\
$\mathrm{H}_{2}$ & $\begin{array}{c}\text { Moderating } \\
\text { Effect NC }\end{array}$ & PDP & 1,325 & 0,186 & 1,325 & 0,186 & $\mathrm{NS}$ \\
$\mathrm{H}_{3}$ & $\begin{array}{c}\text { Moderating } \\
\text { Effect ED }\end{array}$ & PDP & 0,316 & 0,752 & 0,316 & 0,752 & $\mathrm{NS}$ \\
\hline
\end{tabular}

Notes: $\mathrm{S}$ = Supported; US = Not Supported

Source: data processed

The results showed that $\mathrm{H}_{1}$ "entrepreneurial orientation had a significant effect on product development performance in family companies" supported. The results of moderating effect networking capability on the influence of entrepreneurial orientation variables on product development performance have no significant effect, so the results of this study prove that $\mathrm{H}_{2}$ "networking capability moderates the effect of entrepreneurial orientation on product development performance on family companies" is not supported, but can be categorized as a predictor of moderation. Moderating effect of dynamic environment variables on the influence of entrepreneurial orientation variables on product development performance has no significant effect, so the results of this study prove that $\mathrm{H}_{3}$ "dynamic environment moderates the effect of 


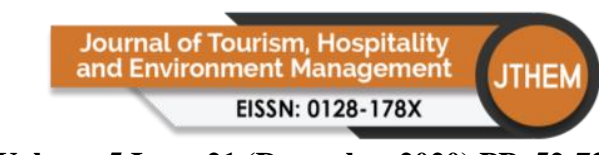

Volume 5 Issue 21 (December 2020) PP. 52-73 DOI 10/35631/JTHEM.521004

entrepreneurial orientation on product development performance on family companies" is not supported, but can be categorized as a potential moderation because the direct effect of dynamic environment on product development performance is not significant.

\section{Disscussion}

The results showed that family businesses in the technological era were more courageous in taking risks aggressively by implementing bolder strategies. One long-term strategy is to try to increase the product / service line. No wonder that the conditions that occur in the market have been accommodated in a long-term strategy so that when faced with ever-changing conditions, the company is ready with various strategies that have been designed. Companies tend to implement various research activities and innovative product / service developments. An interesting thing that can be found in this research is that there are two variables that may have a moderating role. The results showed different results on the role of moderating environmental dynamism which is an external condition of the company that might have an effect on organizational performance. The unpredictable and very rapid condition of external changes does not have a significant impact on the performance of product / service development. This result did not support prior research which showed that dynamic environment tends to positively moderate the entrepreneurial orientation and performance relationship (Lumpkin and Dess, 2001; Casillas et al., 2011). Then, it means in the family business literatures, when environmental dynamism increases, family firms with higher levels of entrepreneurial orientation will have stronger performance (Casillas et al., 2010; Cruz and Nordqvist, 2012). Environmental dynamism in this research does not play a role in strengthening the influence of the company's strategic orientation on the performance of product development, but in certain conditions only has the potential to increase or decrease the performance of product development so that it can be categorized as a potential moderator, why is that because basically in the digital era 4.0 every company especially companies that have been able to enter the survival phase have readiness (alertness) in the long-term orientation. Even companies tend to be better equipped to deal with changing market needs. In the context of the family business, the readiness of the company in maintaining the longevity of organizational sustainability has entered the orientation of the succession initiation stage. In this research, almost all of the representation of the next generation has actively contributed in the management of the family business, so that the alertness button has begun to function so that the readiness in facing environmental dynamism is more optimal.

The relationship between strategic orientation, especially focused on entrepreneurship and product development has proven that networking capabilities represent the specific capabilities needed by companies so that they can be used to support the procurement, integration, and exploitation of network resources for product development (Dyer \& Singh, 1998; Mu \& Di Benedetto, 2012; Mu, 2013; Mu, 2014). Networking ability is needed to realize the synergy of family businesses with those who contribute to the overall performance of the organization. Networking ability is the company's competence in optimizing network resources to support creating products and services that have added value. The network entity in the family business is not only related to the network of stakeholders, but also deeper in managing strategic networks that contribute to the performance of the organization. The results show that networking capability acts as a moderator predictor indicate that networking capabilities not only play a role in increasing the influence of the company in the long-term orientation in product development, but rather the ability to network has the ability and potential to be antecedent that can affect the performance of product development. 


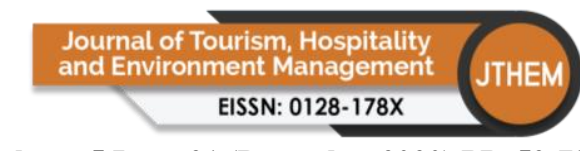

Volume 5 Issue 21 (December 2020) PP. 52-73 DOI 10/35631/JTHEM.521004

When networking capability is high, strategic planning and performance improvement relationships are made where there is some research related to strategic planning for product development, it is important for companies to encourage internal and external networks to strengthen the development of product development strategies (Mu, J., et al. ., 2016). These results indicate that strategic planning is necessary but not sufficient to improve performance (Matsuno et al., 2002; Kirca et al., 2005; Kumar et al., 2011; Mu \& Di Benedetto, 2012). Therefore, having entrepreneurial support can help companies stay in accordance with market opportunities and changing customer needs (Mu J., et.al, 2016). This result supported that entrepreneurial orientation supports the company through external and internal resources, so the company improved company performance and excellence (Teece, 2007; Mu \& Di Benedetto, 2012; Mu, 2013, 2014, 2015). The effects of interactions between entrepreneurship orientation, network capability, product development provide insights on successful NPD product development projects where network capabilities involve important additives from supporting entrepreneurship on product development, (Mu, et. al., 2016). An example in a family business is competence in networking more in the selection and building relationships between partners / networks that can be relied upon and at any time can provide support accurately. This can be realized through the quality of relationships between partners and quality in maintaining long-term relationships, especially to support the longevity of family businesses.

\section{Conclusion}

Based on the hypotheses that have been developed, this study can conclude that family companies that have entered the survival phase have an entrepreneurial long-term orientation, which means they are able to manage opportunities innovatively by being more proactive in all conditions, so as to have an effect on the performance of product development /service. Networking capability has opportunities as an antecedent that can affect the performance of product / service development while environmental dynamism is only a potential moderator. The results of the study are less able to support some of the previous studies so that this study still has results that are inconsistent with previous research. Therefore, it can provide opportunities for further research to be able to apply to different research settings so that they can contribute and enrich knowledge empirically.

This research has limitations that lead to future research. First, the data on the independent and dependent variables are mainly perceptual. Researchers have been careful in collecting data from different sources, the data obtained are cross-sectional so that they cannot capture dynamic interactions between entrepreneurial orientation, network capabilities, environmental dynamism on the performance of product development over time. Thus, future research is expected to use secondary data and are longitudinal in nature. In addition, the data obtained came from Java and Bali. Although Rauch et al. (2009) meta-analysis found no differences in the relationship of strategic orientation performance across continents, the results might not be generalizable to organizations in other countries. Sampling for future research in various countries is needed to overcome this problem. Second, researchers collect data from different industries so that it might affect the company's performance results because the type of industry can determine the company's technological opportunities (Gatignon \& Xuereb, 1997), product profitability (Teece, 2007), new product commercialization, customer satisfaction with new products and the speed of commercialization of new products (Song \& Parry, 1997). Future research is expected to be able to collect data from various industries to provide more interesting results. 


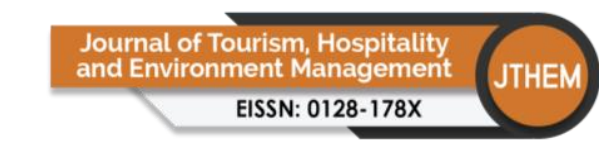

Volume 5 Issue 21 (December 2020) PP. 52-73 DOI 10/35631/JTHEM.521004

\section{References}

Abdillah, W., \& Jogiyanto. (2015). Partial Least Square (PLS) Alternatif Structural Equation Modeling (SEM) dalam Penelitian Bisnis (edisi 1). Yogyakarta: ANDI.

Adomako, S., \& Danso, A. (2018). Regulatory environment, environmental dynamism, political ties, and performance. Journal of Small Business and Enterprise Development.

Agbim, K. C., Oriarewo, G. O., \& Zever, T. A. (2014). Moderating effects of individual entrepreneur and enterprise characteristics on the relationship between business environmental scanning behaviour and entrepreneurial performance. Journal of Business Studies Quarterly, 6(1), 248.

Anwar, M., Rehman, A. U., \& Shah, S. Z. A. (2018). Networking and new venture's performance: mediating role of competitive advantage. International Journal of Emerging Markets, 13(5), 998-1025. https://doi.org/10.1108/IJoEM-07-2017-0263

Asif, M., \& de Vries, H. J. (2015). Creating ambidexterity through quality management. Total Quality Management \& Business Excellence, 26(11-12), 1226-1241.

Atuahene-Gima, K. (2005). Resolving the capability-rigidity paradox in new product innovation. Journal of marketing, 69(4), 61-83.

Atuahene-Gima, K., \& Ko, A. (2001). An empirical investigation of the effect of market orientation and entrepreneurship orientation alignment on product innovation. Organization Science, 12(1), 54-74.

Baron, R.M. and Kenny, D.A. (1986). The moderator-mediator variable distinction in social psychological research: conceptual, strategic, statistical considerations. Journal of Personality and Social Psychology, 51 (6), 1173-1182.

Becherer, Richard C. and Maurer, John G. (1997). The moderating Effect of Environmental variables on the entrepreneurial and marketing orientation on the entrepreneur-led firms. Entrepreneurship Theory and Practice. 87 (1), 47-58.

Bergen, S. A., and McLaughlin, C. P. (1988). The R\&D/Production Interface: A Four-country Comparison. International Journal of Operations \& Production Management.

Benner, M. J., \& Tushman, M. L. (2003). Exploitation, exploration, and process management: The productivity dilemma revisited. Academy of management review, 28(2), 238-256.

Bhuian S N.; Menguc, B. and Bell S J. (2005). Just Entrepreneurial Enough: The Moderating Effect of Entrepreneurship on the Relationship Between Market Orientation and Performance, Journal of Business Research, Vol. 58, No. 1, pp. 9-17.

Birkinshaw, J., \& Gupta, K. (2013). Clarifying the distinctive contribution of ambidexterity to the field of organization studies. Academy of Management Perspectives, 27(4), 287298.

Casillas, J.C., Moreno, A.M., and Barbero, J.L. (2011). Entrepreneurial orientation of family firms: family and environmental dimensions. Journal of Family Business Strategy, Vol. 2 No.4, pp. 90-100.

Casillas, J.C., Moreno, A.M., and Barbero, J.L. (2010). A configurational approach of the relationship between entrepreneurial orientation and growth of family firms. Family Business Review. Vol. 23, pp. 27-44.

Chang, W., \& Taylor, S. A. (2016). The effectiveness of customer participation in new product development: A meta-analysis. Journal of Marketing, 80(1), 47-64.

Cohen, W. M., \& Levinthal, D. A. (1990). Absorptive capacity: A new perspective on learning and innovation. Administrative science quarterly, pp. 128-152.

Cooper, C. (2008). Tourism: Principles and practice. Pearson education.

Covin, J. G. , \& Slevin, D. P. (1986). The development and testing of an organizational-level entrepreneurship scale. In Ronstadt, R. , Hornaday, J. A. , Peterson, R. , \& Vespar, K. 


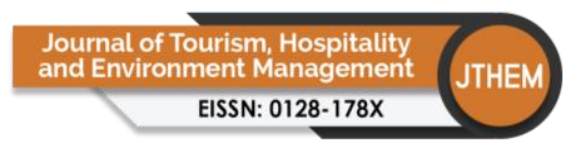

Volume 5 Issue 21 (December 2020) PP. 52-73 DOI 10/35631/JTHEM.521004

H. (Eds.), Frontiers of entrepreneurship research, pp. 628-639. Wellseley, MA: Babson College.

Covin, J.G. and Slevin, D. (1989). Strategic management of small firms in hostile and benign environments, Strategic Management Journal, Vol. 10 No. 1, pp. 75-88.

Covin J.G; Slevin D.P; Schultz R.L. (1994). Implementing Strategic Missions: Effective Strategic, Structural, and Tactical Choices. Journal of Management Studies, Vol. 31, No. 4, pp. 481-503.

Covin, J.G., Green, K. and Slevin, D. (2006), Strategic process effects on the entrepreneurial orientation - sales growth rate relationships. Entrepreneurship Theory \& Practice, Vol. 30 No. 1 , pp. 57-81.

Cruz, C. And Nordqvist, M. (2012). Entrepreneurial orientation in family firms: a generational perspective. Small Business Economics. 38, pp.33-49.

Dimitratos P, Lioukas S. and Carter S. (2004). The Relationship Between Entrepreneurship and International Performance: The Importance of Domestic Environment. International Business Review, Vol. 13, No. 1, pp. 19-41.

Droge, C., Jayaram, J., \& Vickery, S. K. (2004). The effects of internal versus external integration practices on time-based performance and overall firm performance. Journal of operations management, 22(6), 557-573.

Duncan, R. B. (1976). The ambidextrous organization: Designing dual structures for innovation. The management of organization, 1(1), 167-188.

Dyer, J., \& Singh, H. (1998). The relational view: Cooperative strategy and sources of interorganizational competitive advantage. Academy of Management Review, 23, 660 679.

Eisenhardt, K. M., \& Tabrizi, B. N. (1995). Accelerating adaptive processes: Product innovation in the global computer industry. Administrative science quarterly, 84-110.

Faems, D., Van Looy, B., \& Debackere, K. (2005). Interorganizational collaboration and innovation: Toward a portfolio approach. Journal of Product Innovation Management, 22(3), 238-250.

Fang, E. (2008). Customer participation and the trade-off between new product innovativeness and speed to market. Journal of marketing, 72(4), 90-104.

Fritz, W. (1996). Market orientation and corporate success: finding from Germany. European Journal of Marketing. Vol 30 No 8 pp. 77-90.

Gatignon, H., \& Xuereb, J. M. (1997). Strategic orientation of the firm and new product performance. Journal of marketing research, 34(1), 77-90.

George G, Wood D R Jr., and Khan R (2001). Networking Strategy of Boards: Implications for Small and Medium-Sized Enterprises. Entrepreneurship and Regional Development, Vol. 13, No. 3, pp. 269-285.

Grove, J.M.; R.R. Chowdhury, and D.L. Childers. (2015). Co-design, co-production, and dissemination of social-ecological knowledge to promote sustainability and resilience: urban experiences from the U.S. Long Term Ecological Research (LTER) network. Global Land Project News, 11, pp. 6-11.

Hair, J. F., Hult, G. T. M., Ringle, C. M., \& Sarstedt, M. (2017). A Primer on Partial Least Squares Structural Equation Modeling (PLS-SEM). Thousand Oaks. Sage, 165.

Hamel, G. 2000. Leading the Revolution. Boston, MA: Harvard Business School Press.

Han, JK; Kim, N; Srivastava, R.K. (1998). Market orientation and organizational performanceis innovation a missing link. Journal of Marketing 62 (4): 30-45. 


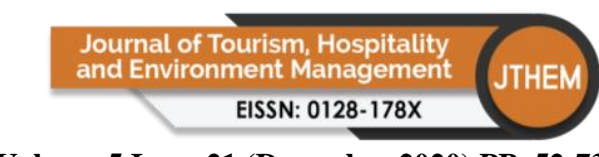

Volume 5 Issue 21 (December 2020) PP. 52-73 DOI 10/35631/JTHEM.521004

Harris, L and Ogbonna, E. (2001). Strategic human resource management, market orientation, and organizational performance. Journal of Business Research. Vol 51 No 2, pp. 157166.

Hitt, M. A., Ireland, R. D., Camp, S. M., \& Sexton, D. L. (2001). Strategic entrepreneurship: Entrepreneurial strategies for wealth creation. Strategic Management Journal, 22, 479491.

Hosseini, S. M., Azizi, S., \& Sheikhi, N. (2012). An investigation on the effect of supply chain integration on competitive capability: an empirical analysis of Iranian food industry. International Journal of Business and management, 7(5), 73.

Hsu, Y.-H. and Fang, W. (2009). Intellectual capital and new product development performance: The mediating role of organizational learning capability. Technological Forecasting \& Social Change 76, 664-677.

Hult, G.T.M., Snow, C.C., \& Kandemir, D. (2003). The role of entrepreneurship in building cultural competitiveness in different organizational types. Journal of Management, 29(3), 401-426.

Hult G T M, Hurley R F and Knight G A. (2004). Innovativeness: Its Antecedents and Impact on Business Performance. Industrial Marketing and Management, Vol. 33, pp. 429-438.

Hung, K. P., \& Chou, C. (2013). The impact of open innovation on firm performance: The moderating effects of internal R\&D and environmental turbulence. Technovation, 33(10-11), 368-380.

Hurley, R and Hult, G.T.M. (1998). Innovation, market orientation, and organizational learning: An integration and empirical examination. Journal of Marketing, 62 (3), 42 54.

Ireland, R. D., Hitt, M. A., \& Sirmon, D. G. (2003). A model of strategic entrepreneurship: The construct and its dimensions. Journal of management, 29(6), 963-989.

Johnson, W. H., \& Filippini, R. (2013). Integration capabilities as mediator of product development practices-performance. Journal of Engineering and Technology Management, 30(1), 95-111.

Khandwalla, P. (1977). The Design of Organizations. Harcourt, Brace, New York, NY.

Kirca, A. H., Jayachandran, S., \& Bearden, W. O. (2005). Market orientation: A metaanalytic review and assessment of its antecedents and impact on performance. Journal of Marketing, 69(April), 24-41.

Kortmann, S., Gelhard, C., Zimmermann, C., \& Piller, F. T. (2014). Linking strategic flexibility and operational efficiency: The mediating role of ambidextrous operational capabilities. Journal of Operations Management, 32(7-8), 475-490.

Koufteros, X., Vonderembse, M., \& Jayaram, J. (2005). Internal and external integration for product development: the contingency effects of uncertainty, equivocality, and platform strategy. Decision sciences, 36(1), 97-133.

Kumar, V., Jones, E., Venkatesan, R., \& Leone, R. P. (2011). Is market orientation a source of sustainable competitive advantage or simply the cost of competing? Journal of Marketing, 75(1), 16-30.

Langowitz, N. S. (1989). Managing new product design and factory fit. Business Horizons, 32(3), 76-79.

Lansberg, I. (1999). Succeeding Generations: Realizing the dream of families in business., $1^{\text {st }}$ edition. Boston: Harvard Business Review Press. ISBN-13: 9780875847429 , pp. 394.

Lau, A. K. (2011). Supplier and customer involvement on new product performance. Industrial Management \& Data Systems. 


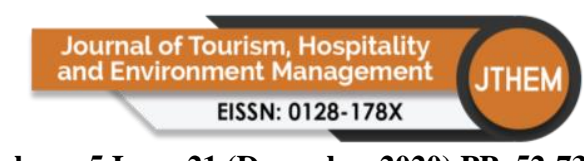

Volume 5 Issue 21 (December 2020) PP. 52-73 DOI 10/35631/JTHEM.521004

Lawson, B., \& Potter, A. (2012). Determinants of knowledge transfer in inter-firm new product development projects. International Journal of Operations \& Production Management.

Lee, C., Lee, K., and Pennings, J. M. 2001. Internal capabilities, external networks, and performance: A study on technology-based ventures. Strategic Management Journal, 22 (special issue): 615-40.

Lumpkin, G.T. and Dess, G. (1996), "Clarifying the entrepreneurial orientation construct and linking it to performance", Academy of Management Review, Vol. 21 No. 1, pp. 135173.

Lumpkin G T and Dess G (2001), "Linking Two Dimensions of Entrepreneurial Orientation to Firm Performance: The Moderating Role of Environment and Industry Life Cycle", Journal of Business Venturing, Vol. 16, No. 5, pp. 429-451.

Luo X, Zhou L, Liu SS. (2005). Entrepreneurial firms in the context of China's transition economy: an integrative framework and empirical examination. Journal of Business Research. Vol 58. Pp. 277-284.

March, J. G. (1991). Exploration and exploitation in organizational learning. Organization science, 2(1), 71-87.

March, J. G. (1995). The future, disposable organizations and the rigidities of imagination. Organization Science, 2(3-4), 427-440.

Mishra, A. A., \& Shah, R. (2009). In union lies strength: Collaborative competence in new product development and its performance effects. Journal of Operations Management, 27(4), 324-338.

Molina-Castillo, F. J., Jimenez-Jimenez, D., \& Munuera-Aleman, J. L. (2011). Product competence exploitation and exploration strategies: The impact on new product performance through quality and innovativeness. Industrial Marketing Management, 40 (7), 1172-1182.

Matsuno, K., Mentzer, J. T., \& Ozsomer, A. (2002). The effects of entrepreneurial proclivity and market orientation on business performance. Journal of Marketing, 66(July), 1832.

Miller, D. (1983). The correlates of entrepreneurship in three types of firms. Management Science, Vol. 29 No. 7, pp. 770-792.

Miller, D. (1988). Relating Porter's business strategies to environment and structure: Analysis and performance implications. Academy of Management Journal, 31, 280-308.

Miller, D. \& Friesen, P. H. (1982). Innovation in conservative and entrepreneurial firms: Two models of strategic momentum. Strategic Management Journal, 3, 1-25.

Miller, D. (2011). Miller (1983) revisited: a reflection on EO research and some suggestions for the future. Entrepreneurship Theory \& Practice, Vol. 35 No. 5, pp. 873-894.

Mintzberg, H. (1973). Strategy-making in three models. California Management Review, Vol. 16, No. 2, pp. 44-53.

Mitrega, M; Forkmann, S.; Ramos, C. And Henneberg, S.C. (2012). Networking capabilities in business relationship - concept and scale development. Industrial Marketing Management. 41 (5), pp. 739-751.

$\mathrm{Mu}$, J. (2013). Networking capability, new venture performance and entrepreneurial rent. Journal of Research in Marketing and Entrepreneurship.

$\mathrm{Mu}$, J. (2014). Networking capability, network structure, and new product development performance. IEEE Transactions on Engineering Management, 61(4), 599-609.

$\mathrm{Mu}$, J., \& Di Benedetto, A. (2011a). Networking capability and new product development. IEEE Transactions on Engineering Management, 59(1), 4-19. 


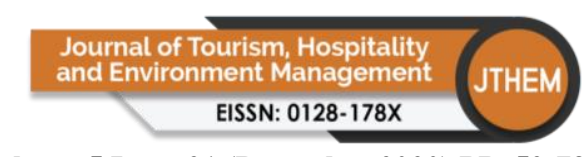

Volume 5 Issue 21 (December 2020) PP. 52-73

DOI 10/35631/JTHEM.521004

Mu, J., \& Di Benedetto, C. A. (2011b). Strategic orientations and new product commercialization: mediator, moderator, and interplay. R\&D Management, 41(4), 337359.

Mu, J., \& Di Benedetto, C. A. (2012). Networking capability and new product development. IEEE Transactions on Engineering Management, 59(1), 4-19.

Mu, J.; Thomas, Ellen; Peng, Gang; Benedetto, Anthony Di. (2016). Strategic orientation and new product development performance: The role of networking capability and networking ability. Industrial Marketing Management, 1-15. http://dx.doi.org/10.1016/j.indmarman.2016.09.007.

Neuman, W. Lawrence. (2015) Metodologi Penelitian Sosial: Pendekatan Kualitatif dan Kuantitatif. Jakarta: PT Indeks.

Partanen, J., \& Haapasalo, H. (2004). Fast production for order fulfillment: Implementing mass customization in electronics industry. International Journal of Production Economics, 90(2), 213-222.

Pfeffer, J and Veiga, J. (1999). Putting people first for organizational success. The Academy of Management Executives. Vol 13 No.2 pp. 37-48.

Piercy, N., Harris, L. and Lane, N. (2002). Market orientation and retailoperatives' expectations. Journal of Business Research. Vol 55 pp. 261-273.

PWC. 2020, 20 April. Family Business Survey. https://www.pwc.com/gx/en/services/familybusiness/family-business-survey-2018.html

Rauch, A., Wiklund, J., Lumpkin, G. T., \& Frese, M. (2009). Entrepreneurial orientation and business performance: An assessment of past research and suggestions for the future. Entrepreneurship theory and practice, 33(3), 761-787.

Reinartz, W.; Krafft, M.; and Hoyer, W.D. (2004). The customer relationship management process: its measurement and impact on performance. Journal of Marketing Research. Vol. 41 No 3, pp. 293-305.

Ryall, M. D., \& Bramson, A. L. (2013). Inference and Intervention: Causal Models for Business Analysis. Routledge.

Ruekert, R. W. (1992). Developing a market orientation: An organisational strategy perspective. International Journal of Research in Marketing, 9, 225-245.

Saren, M. A. (1984). A classification and review of models of the intra-firm innovation process. R\&D Management, 14(1), 11-24.

Sekaran, U., \& Bougie, R. (2016). Research Methods for Business A Skill-Building Approach (Seventh ed). In Library of Congress Cataloging-in-Publication Data. https://doi.org/10.1007/978-94-007-0753-5_102084

Shah, R., \& Ward, P. T. (2003). Lean manufacturing: context, practice bundles, and performance. Journal of operations management, 21(2), 129-149.

Sharma, P.N. and Kim, K.H. (2013). A comparison of PLS and ML bootstrapping techniques in SEM: a monte carlo study: New Perspectives in Partial Least Squares and Related Methods. New York, NY: Springer.

Sharma, S., Durand, R. M., \& Gur-Arie, O. (1981). Identification and analysis of moderator variables. Journal of marketing research, 18(3), 291-300.

Sherman, J. D., Souder, W. E., \& Jenssen, S. A. (2000). Differential effects of the primary forms of cross functional integration on product development cycle time. Journal of Product Innovation Management. An International Publication of the Product Development \& Management Association. 17(4), 257-267.

Slater, S. F. \& Narver, J.C. (1994). Does competitive environment moderate the market orientation-performance relationship? Journal of Marketing. 58 (1), 46-55. 


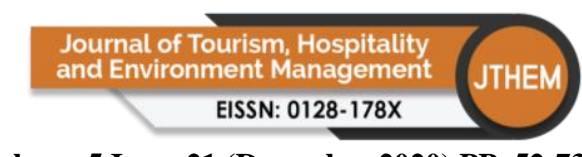

Volume 5 Issue 21 (December 2020) PP. 52-73 DOI 10/35631/JTHEM.521004

Song, M., \& Parry, M. E. (1997). The determinants of Japanese new product successes. Journal of Marketing Research, 34(1), 64-76.

Soosay, C., \& Hyland, P. (2008). Exploration and exploitation: the interplay between knowledge and continuous innovation. International Journal of Technology Management, 42(1-2), 20-35.

Sugiyono. (2010). Metode penelitian kuantitatif dan kualitatif dan R\&D. Bandung: Alfabeta.

Sutcliffe, A., Ryan, M., Doubleday, A., \& Springett, M. (2000). Model mismatch analysis: towards a deeper explanation of users' usability problems. Behaviour \& Information Technology, 19(1), 43-55.

Swaminathan, V. And Moorman, S. (2009). Marketing Alliances, Firm Networks, and Firm Value Creation. Journal of Marketing, 73 (5), 52-69.

Swink, M. L., \& Calantone, R. (2004). Design-manufacturing integration as a mediator of antecedents to new product design quality. IEEE Transactions on Engineering Management, 51(4), 472-482.

Teece, D. J. (2007). Explicating dynamic capabilities: The nature and microfoundations of (sustainable) enterprise performance. Strategic Management Journal, 28(13), 13191350.

Tushman, M. L., \& O'Reilly III, C. A. (1996). Ambidextrous organizations: Managing evolutionary and revolutionary change. California management review, 38(4), 8-29.

Venkatraman, N. (1989). Strategic orientation of business enterprises: The construct, dimensionality, and measurement. Management Science, 20, 510-540.

Voss, C. A., \& Winch, G. M. (1996). Including engineering in operations strategy. Production and Operations Management, 5(1), 78-90.

Wales, W., Gupta, V. and Mousa, F. (2013). Empirical research on entrepreneurial orientatin: an assessment and suggestions for future research. International Small Business Journal, Vol. 31 No. 4, pp. 357-383.

Walter, A.; Auer, M.; Ritter, T. (2006). The impact of network capabilities and entrepreneurial orientation on university spin-off performance. Journal of Bussiness Venturing, 22, 852-874.

Wiklund, J. (1999). The Sustainability of the Entrepreneurial Orientation-performance Relationship. Entrepreneurship Theory and Practice, Vol. 23, No. 1, pp. 37-48.

Wiklund, J., \& Shepherd, D. (2003). Entrepreneurial orientation and small business performance: a configurational approach. Journal of business venturing, 20(1), 71-91.

Wu, Wann-Yih; Chang, Man-Ling; Chen, Chih-Wei. (2008). Promoting innovation through the accumulation of intellectual capital, social capital, and entrepreneurial orientation. R\&D Management 38 (3), 265-277.

Zahra, Shaker A. (1991). Predictors and Financial Outcomes of Corporate Entrepreneurship: An Exploratory Study. Journal of Business Venturing, Vol 6, No. 4, pp. 259-285.

Zahra, Shaker A. (1993). Conceptual Model of Entrepreneurship as Firm Behaviour: A Critique and Extention. Entrepreneuship Theory and Practice. https://doi.org/10.1177/104225879301700401.

Zahra, Shaker A. and Covin, Jeffrey G. (1995). Contextual Influences on the Corporate Entrepreneurship-Performance Relationship: A Longitudinal Analysis. Journal of Business Venturing. Vol 10, 1, pp. 43-58. 


\section{APPENDIX}

\section{Measurement and Loading Factor}

\begin{tabular}{|c|c|c|}
\hline Constructs & Measure & $\begin{array}{c}\text { Loadin } \\
\text { gs }\end{array}$ \\
\hline \multirow{9}{*}{$\begin{array}{l}\text { Entrepreneu } \\
\text { rial } \\
\text { Orientation }\end{array}$} & $\begin{array}{l}\text { In general, the top managers of my firm favor have a strong emphasis on } \mathrm{R} \& \mathrm{D} \text {, technological } \\
\text { leadership, and innovations. }\end{array}$ & 0,536 \\
\hline & $\begin{array}{l}\text { There are very many new lines of products or services has your firm marketed in the past five } \\
\text { years (or since its establishment). }\end{array}$ & 0,740 \\
\hline & Changes in product or service lines have usually been quite dramatic. & 0,736 \\
\hline & $\begin{array}{l}\text { In dealing with its competitors, my firm typically initiates actions to which competitors then } \\
\text { respond. }\end{array}$ & 0,419 \\
\hline & $\begin{array}{l}\text { My firm becomes very often the first business to introduce new products/services, } \\
\text { administrative techniques, operating technologies, etc. }\end{array}$ & 0,549 \\
\hline & My firm typically adopts a very competitive, "undo-the-competitors" posture. & 0,419 \\
\hline & $\begin{array}{l}\text { In general, the top managers of my firm have a strong proclivity for high-risk projects (with } \\
\text { chances of very high returns). }\end{array}$ & 0,818 \\
\hline & $\begin{array}{l}\text { In general, the top managers of my firm believe that environment, it is best to explore it } \\
\text { gradually via cautious, incremental behavior. }\end{array}$ & 0,340 \\
\hline & $\begin{array}{l}\text { When confronted with decision-making situations in- volving uncertainty, my firm Typically } \\
\text { adopts a bold, aggressive posture in order to maximize the probability of exploiting potential } \\
\text { opportunities. }\end{array}$ & 0,791 \\
\hline \multirow{16}{*}{$\begin{array}{l}\text { Environmen } \\
\text { tal } \\
\text { Dynamism }\end{array}$} & It was difficult to forecast technology developments in our industry. & $-0,238$ \\
\hline & The technology environment was uncertain. & $-0,137$ \\
\hline & Technological development was predictable (reversed). & 0,530 \\
\hline & The technology environment was complex. & $-0,046$ \\
\hline & Customer needs and preferences changed rapidly. & 0,192 \\
\hline & Product demands and preferences were uncertain. & 0,315 \\
\hline & It was easy to predict change in Customer needs and preferences. & 0,537 \\
\hline & Market competitive conditions were unpredictable. & 0,107 \\
\hline & $\mathrm{R} \& \mathrm{D}$ investment is in absolute terms. & 0,549 \\
\hline & $\mathrm{R} \& \mathrm{D}$ investment is as percentage of sales. & 0,402 \\
\hline & $R \& D$ investment is as compared to average of main competitors. & 0,449 \\
\hline & $\mathrm{R} \& \mathrm{D}$ investment is as compared to leading competitor. & 0,575 \\
\hline & There are many potential customers for this product to provide a mass-marketing opportunity. & $-0,023$ \\
\hline & Potential customers have a great need for this class of product. & $-0,225$ \\
\hline & The dollar size of the market (either existing or potential) for this product is very large. & 0,545 \\
\hline & The market for this product is growing very quickly. & 0,535 \\
\hline \multirow{14}{*}{$\begin{array}{l}\text { Networking } \\
\text { Capability }\end{array}$} & We have a system in place to help us search locally to find proper network partners. & 0,485 \\
\hline & We have a system in place to help us search globally to identify ap- propriate network partners. & 0,595 \\
\hline & We have a system in place to help us search widely to look for right partners. & 0,782 \\
\hline & We can design appropriate mechanism to navigate the dynamics of partner network. & 0,765 \\
\hline & We can fine-tune network partnership relationships. & 0,605 \\
\hline & $\begin{array}{l}\text { We constantly assess and analyze our relationships with partners so that we know what } \\
\text { adjustments to make. }\end{array}$ & 0,758 \\
\hline & We can dynamically integrate networking activities into our busi- ness operational process. & 0,586 \\
\hline & We can find partners to count on in time when the need arises. & 0,864 \\
\hline & We can be quite accessible to our partners in a timely fashion. & 0,717 \\
\hline & We can get the needed assistance from our partners in an accurate and timely manner. & 0,785 \\
\hline & $\begin{array}{l}\text { Our partners can refer us to a third party who could help if the partners cannot provide direct } \\
\text { help. }\end{array}$ & 0,492 \\
\hline & I am good at using my connections and networks to make things happen at my organization. & 0,819 \\
\hline & $\begin{array}{l}\text { I have developed a large network of colleagues and associates at my organization who I can call } \\
\text { on for support when I really need to get things done. }\end{array}$ & 0,751 \\
\hline & I spend a lot of time and effort at my organization networking with others. & 0,567 \\
\hline
\end{tabular}


Volume 5 Issue 21 (December 2020) PP. 52-73 DOI 10/35631/JTHEM.521004

\begin{tabular}{|c|c|c|}
\hline & I spend a lot of time in my organization developing connections with others. & 0,456 \\
\hline & I am good at building relationships with influential individuals in my organization. & 0,648 \\
\hline & In my organization, I know a lot of important individuals and am well connected. & 0,435 \\
\hline $\begin{array}{l}\text { Product } \\
\text { Developmen }\end{array}$ & $\begin{array}{l}\text { Relative to your firm's other products, this product is very successful in terms of [sales, market } \\
\text { share, return on investment]. }\end{array}$ & 0,716 \\
\hline $\begin{array}{l}\mathrm{t} \\
\text { Performance }\end{array}$ & $\begin{array}{l}\text { Relative to competing products in the market, this product is very successful in terms of [sales, } \\
\text { market share, return on investment]. }\end{array}$ & 0,572 \\
\hline & $\begin{array}{l}\text { Relative to your firm's original objectives for this product, this product is very successful in } \\
\text { terms of [sales, market share, return on in- vestment]. }\end{array}$ & 0,643 \\
\hline & $\begin{array}{l}\text { Relative to your firm's original objectives for this product, this product is very successful in } \\
\text { terms of customer satisfaction. }\end{array}$ & 0,590 \\
\hline & $\begin{array}{l}\text { Relative to your firm's original objectives for this product, this product is very successful in } \\
\text { terms of technological advancement. }\end{array}$ & 0,689 \\
\hline & $\begin{array}{l}\text { Relative to your firm's original objectives for this product, this product is very successful in } \\
\text { terms of overall performance. }\end{array}$ & 0,725 \\
\hline & $\begin{array}{l}\text { In this business unit we meet with customers at least once a year to find out what generation } \\
\text { products/services they will need in the future. }\end{array}$ & 0,437 \\
\hline & $\begin{array}{l}\text { In this business unit, we poll end-users at least once a year to assess the quality of our } \\
\text { products/services. }\end{array}$ & 0,266 \\
\hline & $\begin{array}{l}\text { We often talk with or survey those who can influence our end- users' purchases (e.g., retailers } \\
\text { or distributors). }\end{array}$ & 0,647 \\
\hline & $\begin{array}{l}\text { In this business unit, intelligence on our competitors is generated independently by several } \\
\text { departments. }\end{array}$ & 0,487 \\
\hline & $\begin{array}{l}\text { We periodically review the likely effect of changes in our business environment (e.g., } \\
\text { regulations) on customers. }\end{array}$ & 0,605 \\
\hline & $\begin{array}{l}\text { We have interdepartmental meetings at least once a quarter to discuss market trends } \\
\text { dissemination and developments. }\end{array}$ & 0,700 \\
\hline & $\begin{array}{l}\text { Marketing personnel in our business unit spend time discussing customers' future needs with } \\
\text { other functional departments. }\end{array}$ & 0,610 \\
\hline & $\begin{array}{l}\text { Our business unit periodically circulates documents (e.g., reports, newsletters) that provide } \\
\text { information on our customers. }\end{array}$ & 0,671 \\
\hline & $\begin{array}{l}\text { When something important happens to a major customer or mar- ket, the whole business unit } \\
\text { knows about it in a short time. }\end{array}$ & 0,524 \\
\hline & $\begin{array}{l}\text { Data on customer satisfaction are disseminated at all levels in this business unit on a regular } \\
\text { basis. }\end{array}$ & 0,578 \\
\hline & It takes us forever to decide how to respond to competitor price changes. & 0,429 \\
\hline & For various reasons, we tend to ignore changes in our customers' product/service needs. & 0,182 \\
\hline & $\begin{array}{l}\text { We periodically review our product/service development efforts to ensure that they are in line } \\
\text { with what customers want. }\end{array}$ & 0,584 \\
\hline & $\begin{array}{l}\text { If a major competitor were to launch an intensive campaign targeted at our customers, we would } \\
\text { implement an immediate re- sponse. }\end{array}$ & 0,470 \\
\hline & Customer complaints fall on deaf ears in this business unit. & 0,579 \\
\hline & $\begin{array}{l}\text { Even if we came up with a great marketing plan, we probably would not be able to implement } \\
\text { it in a timely fashion }\end{array}$ & $-0,035$ \\
\hline
\end{tabular}

